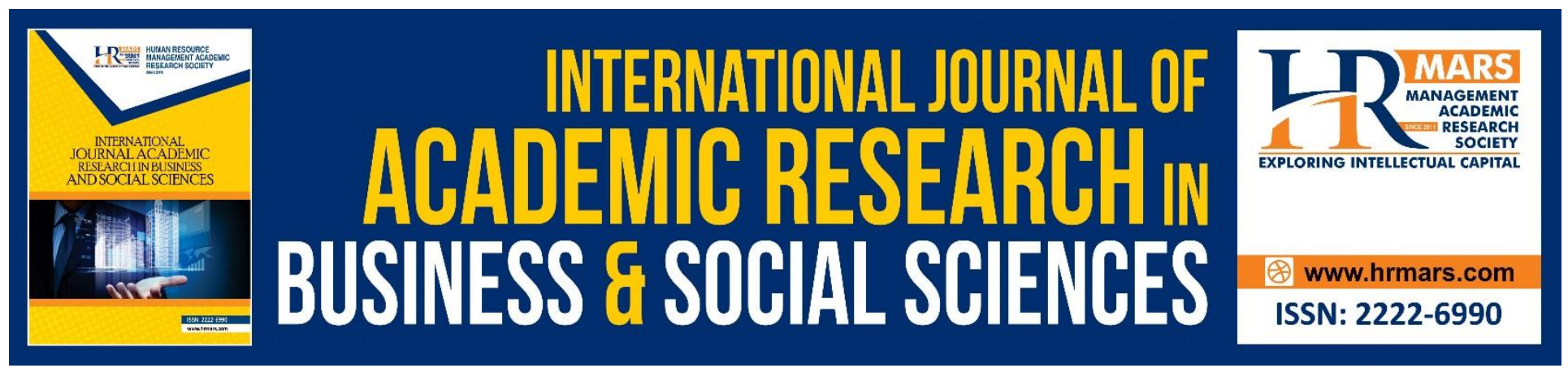

\title{
The Extent of School Management Support of ICT Tools Integration in Teaching and Learning of Kiswahili Language in Public Secondary Schools in Kenya
}

Martin M. Ngavana, Francis Mutua, Peter KibetKoech

To Link this Article: http://dx.doi.org/10.6007/IJARBSS/v8-i9/4677

DOI: $\quad 10.6007 /$ IJARBSS/v8-i9/4677

Received: 17 August 2018, Revised: 27 Sept 2018, Accepted: 29 Sept 2018

Published Online: 15 October 2018

In-Text Citation: (Ngavana, Mutua, \& KibetKoech, 2018)

To Cite this Article: Ngavana, M. M., Mutua, F., \& KibetKoech, P. (2018). The Extent of School Management Support of ICT Tools Integration in Teaching and Learning of Kiswahili Language in Public Secondary Schools in Kenya. International Journal of Academic Research in Business and Social Sciences, 8(9), 1025-1033.

Copyright: (C) 2018 The Author(s)

Published by Human Resource Management Academic Research Society (www.hrmars.com)

This article is published under the Creative Commons Attribution (CC BY 4.0) license. Anyone may reproduce, distribute, translate and create derivative works of this article (for both commercial and non-commercial purposes), subject to full attribution to the original publication and authors. The full terms of this license may be seen at: http://creativecommons.org/licences/by/4.0/legalcode

Vol. 8, No. 9, September 2018, Pg. 1025 - 1033

Full Terms \& Conditions of access and use can be found at http://hrmars.com/index.php/pages/detail/publication-ethics 


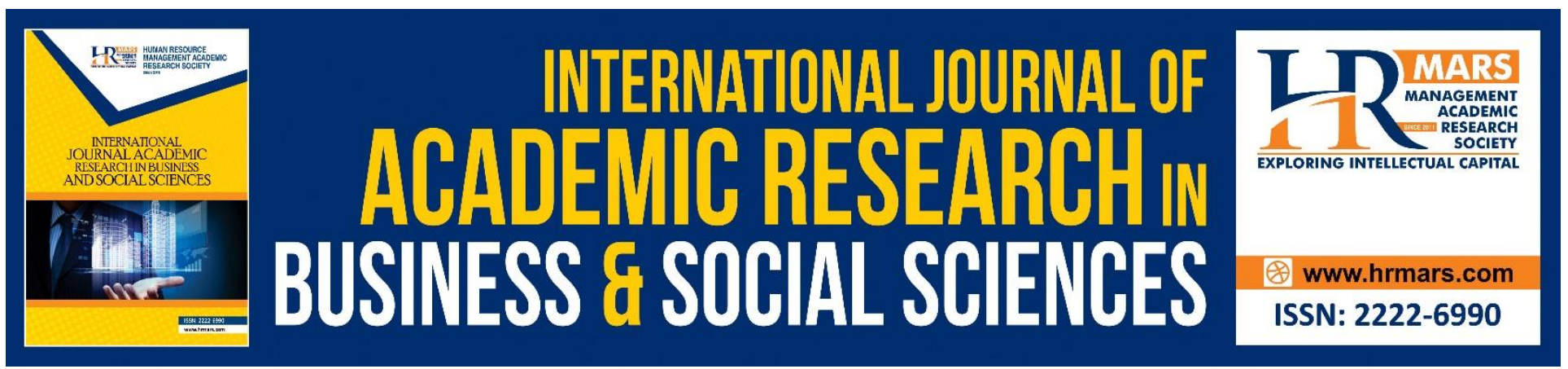

\title{
The Extent of School Management Support of ICT Tools Integration in Teaching and Learning of Kiswahili Language in Public Secondary Schools in Kenya
}

\author{
Martin M. Ngavana \\ Machakos University, School of Education, Department of Educational Communication and \\ Technology, Nunguni, Kenya \\ Email: mwalilimartin@yahoo.com \\ Dr. Francis Mutua \\ Department of Educational Communication ad Technology, Machakos University \\ Email: bfmutua@mksu.ac.ke \\ Dr. Peter KibetKoech \\ Department of Educational Communication ad Technology and Early Childhood Education \\ Machakos University \\ Email: drkibet@mksu.ac.ke
}

\section{Abstract}

Integration of technology in education is considered all over the world as a strategy of transforming the quality of education. The purpose of the study was to establish the extent of school management support in ICT integration in teaching and learning of Kiswahili language in public secondary schools in Kenya. The study adopted a descriptive survey design. The study was carried out in Kilungu subcounty in western region of Makueni County. The study targeted a population of 22 secondary schools in Kilungu Sub-county, 22 Principals, and 48 Kiswahili language teachers. Stratified sampling was used to group the schools in three categories while purposive sampling was used to sample the 48 teachers in these schools. 22 principals were purposive sampled Data collection instruments used were questionnaires for teachers and interview schedules for principals. Data was collected through administering teachers' questionnaires by the researcher, interviewing principals. Statistical package for social sciences (SPSS) version 23 was used to analyze the data. The study established that $18.17 \%$ of the Kiswahili teachers agreed that school management encourages teachers to acquire IT skills and 
also motivates them to use ICT based tools in the teaching and learning of Kiswahili language. Based on the findings of this study, the researcher concludes that the school management cannot fully support the use of ICT tools in teaching and learning of Kiswahili language due to financial constraints and high cost of ICT tools. The study recommends that the ministry of education should supply computers and other ICT tools to all schools in Kenya and make it compulsory for all schools to integrate ICT in the teaching and learning process. The School management should formulate ICT integration policy in their schools that enable teachers to use ICT tools in the teaching and learning process.

Keywords: ICT, Kiswahili, Integration, Teaching, Learning, Kilungu sub-county, Kenya

\section{Background of the Study}

Information and communication technology (ICT) tools play an important role in education. ICT has the potential to accelerate, enrich and deepen skills to motivate and engage learners to relate school experience to work practices, create economic variability for tomorrow's workers as well as strengthening teaching and helping schools to change (Mingaine, 2013).

According to Mikre (2011)ICT is considered to be the key of unlocking the skills and knowledge of our learners. It is also considered to be the gateway for learning of the $21^{\text {st }}$ century skills. Education systems are embracing ICT tools integration globally in teaching and learning process. ICT tools provide a dynamic and proactive teaching and learning environment. Teachers are therefore required to use ICT tools in their teaching process to replace their traditional methods in this digital era especially for the purpose of improving the quality of teaching and learning. Nowadays, ICT tools facilitate not only the delivery of the lesson but also the learning process itself. ICT tools include but not limited to computer based technologies, data storage devices, desktops, laptops, broadcasting technologies i.e. radio and television which are used as instructional tools at schools.

Ghavifekr, Kunjappan, Ramasamy, and Anthony (2016)states that the ministry of education in Malaysia, has noted the importance of ICT integration in primary and secondary curriculum. The element of ICT was included as one of the education blue print 2013-2025 as the national future development focus under the ICT transform focus, M.o.E is trying to strengthen ICT capacity in different stage, one being the review of the current ratio of teacher to student for ICT devices allocation, ICT innovation on distance learning. The M.o.E introduced a few ICT education programs to create interactivity during the teaching and learning process. The intention of Malaysian government was to upgrade the quality of ICT skills among schools in the remote areas.

Kenya has emphasized the importance of integrating ICT tools in teaching and learning activities through Kenya Education Sector Support Program (KESSP). This is evidenced through the introduction of National ICT Strategy for Education and Training (Farrell, 2007)which enables the country to achieve global goals like Education for All (EFA) (Waema, 2005). Kenyan government has taken steps to support and implement the strategy with an aim of enhancing the quality of teaching and learning. Kiswahili language is a compulsory subject in Kenyan school education system (Wanjiku-Omollo, 2014). 
INTERNATIONAL JOURNAL OF ACADEMIC RESEARCH IN BUSINESS AND SOCIAL SCIENCES Vol. 8, No. 9, Sept. 2018, E-ISSN: 2222-6990 @ 2018 HRMARS

Farrell (2007)states that one of the sub-plans of $\mathrm{NICl}$, (2010) is that in Rwanda the M.O.E in collaboration with other agencies strategized on training primary teachers and also secondary school teachers on ICT in education .Another strategy is the development of e-learning content. The M.o.E funded training of 3000 secondary school teachers on ICT training basic skills.

Teachers teach Kiswahili language using both traditional and modern approaches of teaching. The commonly instructional materials include; use of chalk and blackboard, textbooks, charts, pictures and realis. Kiswahili curriculum has undergone revision by the curriculum developers i.e. Kenya Institute of Curriculum Development (K.I.C.D) for a number of years the interest being in 2002; and some of the changes being implemented include integration of ICTs in teaching and learning of Kiswahili language (Kinuthia, 2009). These changes include adopting new pedagogical practice such as ICTs integration.

According to Unwin (2009) Integration of ICTs in teaching and learning of Kiswahili can enable the learners interact with the computer based resources and even enable teachers achieve their objective and improve the quality of education. Power point presentation, web downloads of audio and video, recording, commercially produced Compact Disks (CDs) and Digital Video Disks (DVDs) once integrated in language teaching assist in development of the content and four key language skills; listening, speaking, reading and writing. They also enhance the teaching and learning of Kiswahili language. This is the only way a Kiswahili language teacher can bridge the gap between the teacher-centered approaches of teaching to learner-centered by introducing computer related infrastructure as a medium of instruction in the classroom. Crusan (2012)adds that one of the advantages of integrating ICTs in teaching and learning of a language is that it motivates both learners and teachers in making the learning process more exciting and enjoyable. It also allows multi-sensory learning because multimedia computers combine text, sound and colorful moving images such as hypermedia that engage learners in learning process and which also suits hearing impaired learners. Secondly, teachers and learners no longer have to rely solely on printed books for their educational need; they can access some learning materials from the internet in order to enhance their content and knowledge. This enhances learner centered approach as learners become active in research work.

According to the KNEC report of 2016, one of the reasons why Kiswahili results continue deteriorating is because some of the teachers continue using teacher centered approaches in their teaching activities and do not integrate ICTs which is more learner-centered. This study aimed at investigating the extent of school management support in ICT integration in teaching and learning of Kiswahili language in public secondary schools in Kenya.

\section{Literature Review}

Mingaine (2013) argue that school leaders support implementation of the technology in their school through acquiring the needed infrastructure. However, the cost of infrastructure is too high hence you find few schools adopt ICT tools. In order to integrate ICT in teaching and learning process, there 
has to be proper planning at the school level. The school is expected to provide the necessary ICT tools for the teachers and learners to use (Karimi, 2012). According to Obonyo (2013) says that unrestricted access to training would amount to effective use of computers if teachers are expected to use ICT tools in a meaningful way. In this regard, they suggested that strong leadership is critical to ICT integration and implementation in teaching and learning process.

A study done by Maithya (2013) indicated that Kiswahili language taught through different approaches that encourage learners' involvement, ICT integration if done well by teachers could increase the learners learning activities and improve their performance in general. Studies done by Allen and Seaman (2007)show that, about 3.2 million students in America integrate ICT in their learning activities in science subjects.

Haggins and Moseley (2011) states that there is always a problem when it comes to acquisition of the necessary infrastructure from administrations who are the decision makers of any learning institution. The support given by administration is vital for the enhancement of ICT in the teaching and learning process as Hawkins (2002) noted that teachers need support in good practice and leadership from the administration so that they may become more effective in their teaching work.

\section{Theoretical Framework}

This study was guided by Bruner's constructivism theory (1990) and TPCK Model by Koehler and Mishra (2005). According to Bruner, invention or creativeness is the process of coming up with new knowledge on the basis of learners' experience. Hung and Khine (2006), states that constructivist learning theory has been identified as the most suitable for the use of ICT in teaching and learning. Constructivist learning theory is based on education psychology. The basic idea in this theory is that learning is an active and constructive process. The theory operates on the principle that learners are viewed as information constructor and new information is linked with prior knowledge. Use of technology affords learners to have high level of critical thinking and problem solving. This theory place more emphasis on sensory input, something that has been overlooked by traditional educators where their learners are passive as opposed to learners in constructivist who are fully involved in the learning process.

The researcher used the theory because; the learner uses the knowledge that he/she already has in setting new knowledge through the teacher. Teachers who take the direction of constructivism must emphasize what the learner know and relate it to what they teach. The constructivism theory emphasizes that teachers are supposed to involve learners effectively in the learning and teaching process. When a teacher uses ICT in his/her teaching, the learners are involved effectively in the learning and teaching process. This will also enable learners to communicate and interact effectively in class. Language also plays important role in learning because thinking takes place in communication.

The research was also guided by TPCK model whose aim entails the understanding and negotiating of relationship among three knowledge components, namely: Technology, Pedagogy and Content. 
INTERNATIONAL JOURNAL OF ACADEMIC RESEARCH IN BUSINESS AND SOCIAL SCIENCES Vol. 8, No. 9, Sept. 2018, E-ISSN: 2222-6990 @ 2018 HRMARS

This model was developed by Koehler and Mishra (2005)for making decisions on integration of ICT that causes representation of new concepts and requires developing sensitivity to dynamics, transactional relationship between all the three components so as to enhance effective and meaningful teaching and learning process.

TPCK is a framework for knowledge for technology integration. The components of TPCK model are:

T- Technology which entails all forms of technologies such as computers, video, projectors, radio, television, mobile phone among others which a teacher can choose that suits his content or learners.

P- Pedagogy describes the methods of teaching and learning.

C- Content is the subject matter to be taught or to be learnt.

\section{Research Design and Methodology}

A research design is the plan and structure of investigation so conceived as to obtain answers to research questions. It constitutes the blue print for the collection, measurement and analysis of data, and aids the researcher in the allocation of his limited resources (Munyoki \& Mulwa, 2012). The research used mixed method approach i.e. qualitative method and quantitative method. The study adopted a descriptive survey design. A survey design integrates different methods in collecting data. In this study, descriptive survey aims at exploring the extent of school management support in ICT use in teaching and learning of Kiswahili language. The data was analyzed through concurrent triangulation since the study involved concurrent but separate collection of qualitative and quantitative data.

Research Findings and Discussion

Below are the findings and discussion of the study.

Descriptive Analysis

\begin{tabular}{|c|c|c|c|c|c|}
\hline & $\begin{array}{l}\text { SD } \\
\%\end{array}$ & D & $\begin{array}{l}\mathbf{N} \\
\%\end{array}$ & A & $\begin{array}{l}\text { SA } \\
\%\end{array}$ \\
\hline The school management provides the school with ICT tools. & 2.27 & 47.73 & 0.00 & 40.91 & 9.09 \\
\hline $\begin{array}{l}\text { The school management supports the use of ICT in teaching } \\
\text { and learning of Kiswahili language. }\end{array}$ & 2.27 & 13.64 & 2.27 & 79.55 & 2.27 \\
\hline $\begin{array}{l}\text { The school management motivates teachers to use ICT in } \\
\text { teaching and learning of Kiswahili language. }\end{array}$ & 2.27 & 25.00 & 6.82 & 59.09 & 6.82 \\
\hline $\begin{array}{l}\text { The school management encourages teachers to acquire } \\
\text { ICT skills through training }\end{array}$ & 2.27 & 0.00 & 9.09 & 79.55 & 9.09 \\
\hline $\begin{array}{l}\text { The school management has procured some ICT tools such } \\
\text { as: computers, TVs, radios, projectors among others. }\end{array}$ & 18.18 & 0.00 & 34.09 & 31.82 & 15.91 \\
\hline
\end{tabular}

Table 1.0 shows that $40.91 \%$ and $9.09 \%$ of the Kiswahili teachers agreed and strongly agreed respectively that the school management provides the school with ICT tools. Hence, the school management provides the school with ICT tools according to $50 \%$ of the teachers. $79.55 \%$ and $2.27 \%$ of the Kiswahili teachers agreed and strongly agreed respectively that the school management 
supports the use of ICT in teaching and learning of Kiswahili language. Thus, the school management supports the use of ICT in teaching and learning of Kiswahili language according to majority of the teachers. $59.09 \%$ and $6.82 \%$ of the Kiswahili teachers agreed and strongly agreed respectively that the school management motivates teachers to use ICT in teaching and learning of Kiswahili language. Thus about $65.91 \%$ of the teachers argue that the school management motivates teachers to use ICT in teaching and learning of Kiswahili language.79.55\% and $9.09 \%$ of the Kiswahili teachers agreed and strongly agreed respectively that the school management encourages teachers to acquire ICT skills through training. Thus, majority of the teachers notes that the school management encourages teachers to acquire ICT skills through training. $31.32 \%$ and $15.91 \%$ of the Kiswahili teachers agreed and strongly agreed respectively that the school management has procured some ICT tools such as: computers, TVs, radios, projectors among others. Thus based on about $47.23 \%$ of the Kiswahili teachers the school management has procured some ICT tools such as: computers, TVs, radios, projectors among others.

Regarding school management support in ICT tools integration in teaching and learning of Kiswahili language, majority of the Kiswahili teachers, noted that the school management supports the use of ICT in teaching and learning of Kiswahili language and encourages teachers to acquire ICT skills through training. Moreover, the school management motivates teachers to use ICT in teaching and learning of Kiswahili language according to $65.91 \%$ of the teachers and also based on $55 \%$ of the principals. Similarly, based on $50 \%$ of the Kiswahili teachers, the school management provides the school with ICT tools; and has procured some ICT tools such as: computers, TVs, radios, projectors among others.

Similar findings were established by Maithya (2013) that the school management supports the use of ICT in teaching and learning and encourages teachers to acquire ICT skills. Similarly, Mingaine (2013) argued that school leaders support implementation of the technology in their school through acquiring the needed infrastructure. All the principals visited and interviewed also noted that they do support Kiswahili language teachers with support to acquire further ICT skills.

\section{Thematic Analysis}

Principals were also interviewed on school management support in ICT tools integration in teaching and learning of Kiswahili language. One of the principals noted that, "there is need for standby generators in case of power failure; capacity building workshops training; and equipping ICT room." Another one indicated that, "I have already procured a laptop, projector, a television and some computers." This correlates with Mingaine (2013) who argued that school leaders support implementation of the technology in their school through acquiring the needed infrastructure. This affirmed that school management support ICT tools integration in Kilungu sub-county.

\section{Conclusions and Recommendation}

The school management supports the use of ICT tools in the teaching of Kiswahili language. This is also evidenced by some school management procurement of some ICT tools for the school. However, the article also shows that about $50 \%$ of the school management does not support the use ICT tools 
in the teaching and learning of Kiswahili language. Based on the findings, the researcher makes the following recommendations: The ministry of education should supply computers to all schools in Kenya and make it compulsory for all schools to integrate ICT in the teaching and learning process. School management should formulate ICT integration policy in their schools that enable teachers to use ICT tools in the teaching and learning process. A comparative study can be done to assess the factors that influence the use of ICT tools in secondary schools in the sub-county.

\section{References}

Allen, I. E., \& Seaman, J. (2007). Making the grade: Online education in the United States, 2006: ERIC. Crusan, D. J. (2012). Evaluating Computer-Assisted Language Learning: An Integrated Approach to Effectiveness Research in CALL. Wright State University - Main Campus.

Farrell, G. (2007). Survey of ICT and Education in Africa ICT in Education in Kenya. Kenya: Country Report

Ghavifekr, S., Kunjappan, T., Ramasamy, L., \& Anthony, A. (2016). Teaching and Learning with ICT Tools: Issues and Challenges from Teachers' Perceptions. Malaysian Online Journal of Educational Technology, 4(2), 38-57.

Government of Kenya. (2005). Sessional Paper No 1 of 2005: A Policy Framework For Education, Training and Research. Nairobi: Government Printers.

Haggins, S., \& Moseley, D. (2011). Teachers' thinking about ICT and learning: believes and outcomes. (Journal of Teacher Development Studies, 2(191).

Hung, D., \& Khine, M. S. (2006). Engaged learning with emerging technologies. Nangag Technological university. Singapore: Springer Publisher.

K.I.E. (2002). Secondary Education Syllabus, volume one. Nairobi: K.I.E.

Karimi, G. A. (2012). Factors Affecting The Use Of Information And Communication Technology In Teaching And Learning In Secondary Schools In Kangema-Murang'a County. (Degree Of Master Of Education), Kenyatta University.

Kinuthia, W. (2009). Educational Development in Kenya and the Role of Information and Communication Technology International Journal of Education and Development using ICT [Online], 5(2).

Koehler, M. J., \& Mishra, P. (2005). What happens when teachers design educational technology? The development of technological pedagogical content knowledge. Journal of educational computing research, 32(2), 131-152.

Kothari, C. R. (2004). Research methodology: methods and techniques. Jaipur, Rajasthan ,India: New Age International.

Maithya, P. M. (2013). Evaluation of Implementation of the Revised Kiswahili Curriculum: A Case of a Teachers' College in Kenya. Journal of Education and Practice, 4(1), 52-56.

Mikre, F. (2011). The roles of information communication technologies in education: Review article with emphasis to the computer and internet. Ethiopian Journal of Education and Sciences, $6(2), 109-126$.

Mingaine, L. (2013). Challenges in the implementation of ICT in Public secondary schools in Kenya. International J. Soc. Sci. \& Education, 4(1), 224-238. 
Mugenda, O. M., \& Mugenda, A. G. (2008). Social science research: Theory and principles. Nairobi: African Centre for Technology Studies.

Munyoki, J. M., \& Mulwa, A. S. (2012). Social Science Research Hand Book. Nairobi, Kenya: Downtown Printing Works Ltd.

Obonyo, S. O. (2013). Use Of Information Communication Technology In Teaching And Learning Processes In Secondary Schools In Rachuonyo South District, Homa-Bay County, Kenya. (Degree of Master of Education in Curriculum Studies), University of Nairobi.

Unwin, T. (2009). ICT4D: Information and communication technology for development: Cambridge University Press.

Waema, M. T. (2005). A brief history of the development of an ICT policy in Kenya.

Wanjiku-Omollo, R. (2014). Effects of language policy in the school on the learning of Kiswahili in Kapseret Division, Uasin Gishu County, Kenya. Journal of Research \& Method in Education, 4(4), 15-19. 